\title{
LA DIVERSIDAD DE PROYECTOS POLÍTICOS EN EL PRIMER DEBATE PRECONSTITUCIONAL ESPAÑOL: CANGA ARGÜELLES, RIBELLES Y BORRUL EN EL CONTEXTO DE LA POLÍTICA VALENCIANA*
}

por

\section{CARMEN GARCÍA MONERRIS}

Departamento de $\mathrm{H}^{\mathrm{a}}$ Contemporánea

Universitat de València

RESUMEN: El decreto de convocatoria de Cortes de 22 de mayo de 1809 de la Junta Suprema del Reino supuso para España el inicio de un debate político de gran intensidad a través del cual se fueron concretando los distintos posicionamientos políticos y los perfiles diversos de un primer liberalismo en el contexto de la profunda crisis constitucional abierta en 1808. Este trabajo quiere ser una aproximación a ese debate desde la óptica "regional" de uno de los territorios o provincias conformadoras de la monarquía borbónica, la del antiguo Reino de Valencia, y a través de tres personajes de escasa fortuna bistoriográfica como José Canga Argüelles, Bartolomé Ribelles y Francisco Xavier Borrull. A través de la lectura de sus obras podremos ir concretando los diversos posicionamientos políticos e ideológicos dentro de un común replanteamiento constitucional de la monarquía que, finalmente, superará los más trillados estereotipos de un liberalismo radical y universalista, por una parte, y de posturas conservadoras e historicistas, por otra.

Palabras clave: Debate preconstitucional. Política. Historia. Liberalismo. Fueros. Historicismo. Patrimonialismo. Constitución. Cortes. Canga Argüelles. Ribelles. Borrull.

ABSTRACT: The decree by which the Cortes of 22 May 1809 were summoned by the Junta Suprema of the realm marked the beginning of a political debate of great intensity in Spain. Through this debate the different political positions and the various ideo-

* Este trabajo forma parte de un proyecto de investigación más amplio subvencionado por la Generalitat Valenciana, GV99-130-1-09. 
logical profiles arising from the deep constitutional crisis of 1808 became gradually crystallised. This article approaches that debate from the regional perspective of one of the territories or provinces of the Bourbon monarchy — namely, the old Kingdom of Valencia - and by examining three figures relatively unknown to bistorians, José Canga Argüelles, Bartolomé Ribelles and Francisco Xavier Borrul. Through an analysis of their works we can identify the diverse political and ideological positions within a broad constitutional reconsideration of the monarchy. This reconsideration will ultimately transcend the stereotypes of a radical and universalising liberalism, on the one hand, and of conservative and bistoricist positions, on the other.

KEY WORDS: Constitutional debate. Constitution. Fueros. Historicism. Patrimonialism. Cortes. Canga Agüelles. Ribelles. Borrul.

Entre 1808 y 1812 se asiste en España, como ya sabemos, a una crisis constitucional de origen profundo, diverso y de trascendentales consecuencias. La antigua monarquía hispánica dará paso a una entidad estatal-nacional de nuevo cuño en la que las proclamas por mantener un cierto grado de continuidad con la vieja tradición histórico-política acabarán por mostrarse no contradictorias con los aspectos más revolucionarios resultantes de tan compleja situación. Y todo ello ocurrirá en medio de una situación excepcional marcada por la desorganización y el vacíó de poder, y una invasión extranjera.

El presente trabajo quiere ser una aproximación al mundo plural y diverso del primer liberalismo desde la óptica «regional» de uno de los territorios que, como el antiguo Reino de Valencia, pudo ejemplificar extraordinariamente un cruce sincrético entre la modernidad uniformizadora que le imprimió el reformismo borbónico y la permanencia, a veces nada inocua ni superficial, de determinadas estructuras e instituciones que hundían sus raices en el pasado foral. Resultado de este entrelazamiento fue un peculiar desarrollo económico en el marco del absolutismo centralista y una no menos peculiar configuración social que, sin solución de continuidad, prestó su carácter radical al proceso desencadenado a partir de mayo de 1808 .

Llegado el momento de pensar la nueva constitución política y social que debería otorgársele a la monarquía, no todo, ni siquiera lo más importante, iba a depender de los respectivos posicionamientos sociales o económicos de los agentes históricos, o de determinaciones más o menos «objetivas». En ese debate colectivo, que tantas ocasiones tuvo de manifestarse en medio de circunstancias excepcionales, no faltaron, ni mucho menos, las influencias debidas a la percepción de una tradición cultural y política que se resistía a desaparecer y que encontraba en esa fractura constitucional de inicio de siglo una ocasión privilegiada para volver a manifestarse. No era la vuelta ingenua a un pasado que se sabía ya definitivamente superado; ni las manifestaciones agónicas de un catolicismo anti-ilustrado, anti-regalista y eminentemente contrario a la filosofía y a la política; pero tampoco era el proyecto o el diseño universalista del liberalismo radical que, no obstante, estuvo también perfectamente representado,

Hispania, LXII/1, núm. 210 (2002) 113-140 
como veremos, en la peculiar coyuntura valenciana que los contemporáneos conocieron como «La Guerra del Francés».

A una y a otra tradición, a la más radical y a la que, de momento, llamaremos historicista, dedicaremos las siguientes páginas, confrontando para ello a tres autores de poca fortuna historiográfica hasta el momento: José Canga Argüelles, Bartolomé Ribelles y Francisco Xavier Borrull. Y aprovechando una de esas circunstancias en que el debate político y la generación de escritos alcanzó un especial grado de intensidad: la convocatoria de Cortes por decreto de la Junta Suprema Gubernativa del Reino de 22 de mayo de 1809.

\section{EL DIFÍCIL EQUILIBRIO ENTRE LA «HISTORIA» Y LA «POLÍTICA» (FRANCESA) DE UN BURÓCRATA LIBERAL}

José Canga-Argüelles (1771-1842), de origen asturiano y futuro Secretario interino de Estado y del Despacho Universal de Hacienda en Cádiz (1811), unió gran parte de su trayectoria profesional, política e intelectual al País Valenciano desde que, a finales de 1804, fuera nombrado Contador General de Ejército de Valencia y Murcia. Tras unos decisivos años como oficial de la Secretaria de Estado y de Hacienda en Madrid, Canga, ya en Valencia, entraría a formar parte de esa amplia pléyade de burócratas y cargos ilustrados que, en el seno mismo de la monarquía absoluta, se empeñaría en una relectura muy especial de las posibilidades reformistas y de racionalización de esa misma monarquía desde las particularidades que ofrecía la estructura económica e institucional valenciana ${ }^{1}$.

1 De Canga Argüelles me he ocupado en varios trabajos míos ya publicados: «Canga Argüelles y el Patrimonio Real de Valencia: 1805-1806» en Estudis d'Història Contemporània del País Valencià (Valencia) 1 (1979) pp. 137-163; «Las Reflexiones sociales de José Canga Argüelles: del universalismo absolutista al liberalismo radical» en Revista de Estudios Políticos (Nueva Época) (Madrid) 94 (octubre-diciembre 1996) pp. 203-228; «Entre la economía política y la administración: el ideario del primer Canga Argüelles (1798-1805)" en GIL CREMADES, J.J. y otros (eds): La configuración jurídico política del Estado liberal en España, Huesca, 1977, pp. 203-215; o mi estudio introductorio a CANGa ARgüElles, J.: Reflexiones sociales y otros escritos, Madrid, Centro de Estudios Políticos y Constitucionales, 2000

El movimiento incorporacionista y regalista de la segunda mitad del siglo XVIII adquirió en el País Valenciano unos tintes muy específicos al encuadrarse, necesariamente, en el marco de la permanencia del Real Patrimonio. Es desde esa especificidad desde la que hablo de una peculiar relectura de las posibilidades reformistas del absolutismo ilustrado que Canga Argüelles, al frente de la institución patrimonial, asumió en herencia de predecesores suyos, como fue el caso del asesor D. Vicente Branchat. Lo que podemos considerar como un amplio proceso de reforma y reestructuración del «espacio de la Corona» (por oposición a los «espacios señoriales») en el País Valenciano, no se limitó sólo al Real Patrimonio, sino que incluyó también otras instancias como la vieja Orden Militar de Montesa en la que destacaron personajes como los miembros de la familia Villarroya o el Contador Martínez de Irujo, predecesor inmediato de Canga Argüelles en la Contaduría General. 
Sus años de experiencia al frente del Real Patrimonio valenciano consolidaron en su ideario un fuerte contenido antiestamental y antiseñorial que, frustradas las expectativas de una reforma desde el corazón mismo de la monarquía, le permitió el paso, sin excesivas violentaciones y en medio de la profunda crisis institucional de 1808, a un activo y expedito liberalismo como miembro de la Junta de Valencia y destacado participante en el proceso revolucionario. A su condición de experto y avezado conocedor de las interioridades administrativas de la maquinaria hacendística de la monarquía, Canga unió su faceta de intelectual ilustrado que había encontrado en la naciente economía política las posibilidades de un pensamiento casi constituyente de la nueva sociedad y, sobre todo, de las nuevas relaciones entre sociedad y política. A todo ello añadiría, entre los años 1808 y 1814, una destacada actividad como publicista, de influencia nada desdeñable en el devenir de las instituciones y de la política valenciana, y de la española en general.

Como sabemos, la constitución de las diversas Juntas provinciales, en tanto que expresión institucional de un nuevo poder soberano, fue seguida inmediatamente de un debate sobre la conveniencia, naturaleza y composición de un gobierno central. En el caso de la Junta de Valencia ello supuso uno de los primeros enfrentamientos claros entre las viejas autoridades y la facción más radical y revolucionaria de los Bertrán de Lís. La contribución de Canga a este debate quedó reflejada en el que constituye uno de sus primeros escritos de esta nueva etapa, la Memoria sobre la constitución de la Junta Central de Gobierno que se trata de formar en España ${ }^{2}$; escrito que, en mi opinión, marca la transición

\footnotetext{
De Branchat, especialmente su obra Tratado de los derechos y regalías que corresponden al Real Patrimonio en el Reyno de Valencia y de la jurisdicción del Intendente como subrogado en lugar del antiguo Bayle General, Valencia, Impr. de Joseph y Tomás de Orga, 1784-1786, que Canga, años más tarde, completaría con su Colección de Reales Ordenes para el gobierno del Real Patrimonio, Valencia, 1806. Sobre Montesa, SÁNCHEZ DURÁ, D.:»La Orden Militar de Montesa. Racionalización y privilegio en la España de los siglos XVIII y XIX» en Historia Social (Valencia) 19 (1994), pp. 3-29.

La experiencia reformista valenciana, de amplios ecos patrimoniales, antiestamentales y antiprivilegiados, constituye un banco de pruebas importantísimo para acercarse a la configuración de determinadas élites burocráticas en la segunda mitad del siglo XVIII y a la consolidación de un discurso que, frustradas las posibilidades de cambio desde dentro, supo enlazar a veces, sin solución de continuidad, con las perspectivas de un liberalismo y de un nuevo Estado que culminara aquello que el «despotismo» había desviado de su normal desarrollo. Sobre el interesante y poliédrico problema de la continuidad/ruptura entre la Ilustración y el liberalismo, se puede consultar Dufour, Gerard: «De la Ilustración al liberalismo» en La Ilustración Española, Alicante, 1986, pp. 363-383.

2 Memoria sobre la constitución de la Junta Central de Gobierno que se trata de formar en España, Valencia, por Joseph Estevan y Hermanos, 1808. El folleto es anónimo, pero no existen dudas sobre la autoría de Canga Argüelles. Además de la referencia de Angel Huarte y Jáuregui en su «Introducción» al Diccionario de Hacienda de José Canga Argüelles, en la B.A.E., Madrid, Atlas, 1968, el propio Canga reprodujo, años más tarde, alguna de las conclusiones finales de esta Memoria en forma de apéndide documental (documento $n^{\circ}$ XVIII) a su obra Observaciones sobre el tomo segundo de la Historia de la Guerra de España que escribió en inglés el teniente coronel Napier, Londres, Imp. M. Calero, 1830, pp. 408-412.
}

Hispania, LXII/1, núm. 210 (2002) 113-140 
desde su etapa reformista anterior en el seno de la institución patrimonial (1805-1808), con fuertes enfrentamientos con los poderes señoriales y municipales constituidos, hasta un neto liberalismo que le llevó a la defensa de un nuevo Estado y de una nueva constitución como instrumentos idóneos para la consumación de las reformas frustradas en el absolutismo.

La Junta Central quedó definitivamente constituida el 25 de septiembre sin una definición clara en sus perfiles ni en su actuación, aunque alejada de la solución mixta Consejo Real-Juntas que era la que propugnaban, con matices entre sí, la Junta de Valencia y el propio Canga. En Valencia, la nueva situación supuso un triunfo momentáneo de la facción más radical en contra de las autoridades más colaboracionistas y/o moderadas. De hecho, la pretensión de Canga de actuar como representante de la de Valencia en la Central se vió frustrada al caer derrotado por dos votos ante la candidatura del Príncipe Pío. Su desplazamiento coyuntural del escenario valenciano se vió reforzado, además, por su marcha a Madrid, capital a la que llegaría coincidiendo con la retirada del primer y breve gobierno josefino y en la que entraría en contacto con el versátil Pedro Cevallos. La presión de las tropas napoleónicas de nuevo sobre Madrid, en diciembre de 1808, obligó a nuestro personaje a regresar a Valencia.

Su retorno a la capital valenciana coincidió con una nueva maniobra del grupo más colaboracionista en contra de la facción más radical, alguno de cuyos representantes fueron encarcelados. Sospecho que fue en ese momento de dificultades para los Bertrán de Lís y sus seguidores, y de cierto envalentonamiento del tanden colaboracionista formado por el Capitán General y por el Intendente, cuando Canga Argüelles unió su destino al sector más burgués y liberal, convirtiéndose en uno de los personajes claves de la nueva situación. En marzo de 1809 eran desplazados del poder, por colaboracionistas, el antiguo Capitán General y el Intendente y sustituidos interinamente por el brigadier José Caro y por Canga Argüelles, respectivamente.

Poco tiempo después, en mayo de 1809 , se promulgaba, como sabemos, el decreto sobre restablecimiento y convocatoria de Cortes que iniciaba en España un extenso debate sobre la naturaleza y la forma de la representación nacional. La contribución de Canga a este debate se tradujo en una de sus obras más importantes de este período, las Observaciones sobre las Cortes de España y su organización que, juntamente con sus Reflexiones sociales, escrita meses más tarde y publicada en 1811 , constituyen la versión más liberal y menos conocida de este autor ${ }^{3}$.

3 El decreto sobre convocatoria de Cortes de la Junta Suprema, de 22 de mayo de 1809, en FERnÁNDEZ MARTín, M.: Derecho parlamentario español (3 tomos), Madrid, Imp. de los Hijos de J.A. García, 1885-1900 (cit. por la edic. de 1992 de Publicaciones del Congreso de los Diputados, T. II, pp. 559-561). A propósito del debate sobre la representación nacional se puede consultar PORTILIO VALDÉS, J. Ma: «Imaginación y representación de la Nación española. (El debate sobre la naturaleza de la representación nacional y la tentativa de Francisco Xavier Uriortua» en Anuario de Historia del Derecho español (Madrid) (1995) pp. 267-320. Una reconstrucción del proceso hasta el último decre- 
Las Observaciones es una obra curiosa, aunque sólo sea por su trayectoria historiográfica. Publicada en septiembre de 1809 con el aval de la propia Junta de Observación y Defensa del Reyno de Valencia, su difusión no debió ser escasa a tenor de la utilización que de la misma se hace en dos obras de signo político distinto, la Práctica y estilo de celebrar Cortes de Antonio Capmany y la Teoría de las Cortes de Martínez Marina ${ }^{4}$. Consta de tres partes bien diferenciadas: en la primera se procede a un estudio histórico-legal sobre «la naturaleza de las Cortes de España» ( léase las de Castilla); en la segunda se efectúa un exámen crítico de aquellas que resultan de la Constitución de Bayona; y en la tercera, en fin, se aborda «la constitución que deberá darse a las Cortes de España, o sea a la representación nacional de ésta».

Desde el primer momento, queda meridianamente claro que el esfuerzo de Canga no se dirige hacia la restauración, por muy modificada que sea, de un organismo histórico o antiguo, sino a «constituir la legal representación de la nación en sus Cortes» (p. 9), lo cual, en la sustantiva dialéctica entre la historia y la política en un momento constituyente, parece colocar a nuestro autor del lado de esta última. Sin embargo, la historia, lejos de ser rechazada o de mostrarse inocua en la determinación política del presente, se encardinará perfectamente en éste, hasta el punto de ser necesaria su revisión y su lectura para un adecuado proyecto constitucional. Estoy de acuerdo con José $\mathrm{M}^{\mathrm{a}}$ Portillo en su idea de que, durante este periodo, fue la historia la que delimitó «el campo de juego en el que más rotundamente se diferenciaban posiciones de implicación política»" ${ }^{5}$ lo cual, entre otras cosas, debería conducirnos a modificar la rígida bipolaridad que siempre hemos establecido entre los «historicistas», más o menos asimilados con los conservadores o tradicionalistas , y los «políticos», identificados con los liberales tout court.

to de la Central de 29 de enero de 1810, en MORÁn ORTI, M.: «La formación de las Cortes (18081810)» en Ayer (Madrid) 1 (1991) pp. 13-36.

Las referencias exactas de las dos obras de Canga Argüelles son Observaciones sobre las Cortes de España y su organización, Valencia, por Josef Estevan y Hermanos, 1809, 107 pp. en octavo; y Reflexiones sociales, o idea para la constitución española que un patriota ofrece a los representantes de Cortes por D.J.C.A., Valencia, en la Imprenta de José Estevan, 1811, 140 pp. en octavo. Esta última fue reeditada el mismo año bajo el título de Instrucciónes para los representantes de las Cortes que ofrece el patriota J.C.A., Valencia, Imp. de José Tomás Nebot, 1811.

4 El dato de las referencias a la obra de Canga en Capmany y Martínez Marina, en PORTILLO VALDÉS, J.Maa: «Imaginación y representación...», ns. 62 y 63 de p. 296 donde, además, se sale al paso de la atribución a Juan Sempere y Guarinos que el editor de la obra de Martínez Marina hace de las Observaciones de Canga, confundiéndolas con las Observaciones sobre las Cortes, y sobre las leyes fundamentales de España, Granada, 1810, ésta sí, obra del escritor alicantino.

5 Vid. PORTILLO VALDÉS, J.M ${ }^{a}$ : «Imaginación y representación...», p. 271 . Un poco más arriba escribe este autor: «La historia -la historia de la nación española y de sus instituciones- jugó en estos años de alumbramiento de las Cortes y de la constitución un papel decisivo y comenzó por interesar a la definición misma de la arquitectura de la representación como cuestión previa y decisiva al proyecto constitucional de fondo».

Hispania, LXII/1, núm. 210 (2002) 113-140 
La historia para Canga, según una clásica concepción de la magister vitae, es, por una parte, suministradora de ejemplos a seguir o a rechazar, pero, por otra, el contenedor que ha ido moldeando una nación que en ningún momento se piensa ni se desea surgida de un puro diseño racional-jurídico, por mucho que "pensar su representación» suponga, en la actual coyuntura, y en sentido aparentemente contrario, todo un ejercicio de voluntad política. Pero también implica «repensar su historia» y hacer de ella una especial lectura como forma de abordar de una determinada manera ese momento político. Su voluntad no es restauracionista; el sentido de su exégesis debe ser considerado en las antípodas del pensamiento conservador.

De la lectura histórica

«se deducen varias reflexiones para conocer a fondo su influencia en el bien y en el mal de la nación, para desengañar a los que juran sobre la antigüedad sin examen ni reflexión, y para provocar la reforma y la buena organización de un cuerpo tan respetable, que deberá cimentar un día la prosperidad de la nación, su independencia y su poder» (pp. 43-44).

Todo un resumen de los objetivos de su razón histórica que en este caso concreto no va a devenir en antagónica de su razón política.

$\mathrm{El}$ - punto de arranque es una nada inocente alusión a los «Estados naciones» como fenómeno «más común en Europa desde la dominación de los bárbaros», en nuestro caso, de los godos ${ }^{6}$, con unos Concilios de Toledo constituidos ya en auténticos «Estados generales de España» (p. 13). Más tarde, cuando como consecuencia de la invasión árabe la nación empiece a reconstruirse desde dos puntos geográficos tan concretos como Covadonga y Sobrarbe y a echar «los cimientos a la feliz constitución que nos ha gobernado por muchos siglos» (p. 8), se cerrará el círculo de una mixtificación reductora de la pluralidad a una de sus partes, Castilla.

Efectivamente, la historia de España de Canga siempre será la historia de Castilla, pese a que gran parte de su experiencia y práctica reformistas en los estertores del absolutismo se hubiese forjado sobre aquella parte del aparato fiscal de la monarquía que más claramente hundía sus raices en un pasado foral, el Real Patrimonio valenciano. Ocurrió, sin embargo, en su caso, como en el de otros muchos en la segunda mitad del siglo XVIII, que ese «espacio de la Corona», netamente patrimonial, sería reinterpretado, no como una manifestación del viejo equilibrio entre «las cosas del Rey» y «las cosas del Reino», de

\footnotetext{
6 Sería conveniente recordar aquí esa "operación» propia de todo momento revolucionario y constituyente, magistralmente expuesta por B. Clavero, en que «el Estado se forja una realidad pretérita; produce no sólo un pasado, sino también una razón, pudiéndose independizar de la del individuo....El Estado ha quedado situado como sujeto de la historia...»; «...la razón de estado es para toda la historia razón del Estado". En ClAVERO, B.: Razón de estado, razón de individuo, razón de bistoria, Madrid, Centro de Estudios Constitucionales, 1991, pp. 47 y 50 y, en general, pp. 15-59.
} 
acuerdo con la vieja constitución estamental, sino como la posibilidad de concreción de un «universalismo» absolutista y antiestamental, capaz, no obstante, de gestar y alimentar en su seno el desarrollo de deseables intereses individuales. Era desde ese uniformismo absolutista, con netas posibilidades reformistas, desde el que el Contador daría el salto hacia un liberalismo también universalista, sesgadamente estatalista y con muy poco espacio para un respeto a los derechos históricamente adquiridos, bien fueran éstos individuales o territoriales. Resulta así paradójico constatar que la trayectoria de Canga Argüelles durante estos decisivos años es incomprensible sin las peculiaridades de la formación social y económica valenciana, aunque sólo sea para concluir en una negación de esas mismas peculiaridades desde un proyecto universalista. Así, la Junta de Valencia parece hacer suyo un escrito en el que, curiosamente, toda la historia de España y de sus Cortes es reinventada desde la exclusiva trayectoria de las castellanas.

Tiene mucha razón el escrupuloso Martínez Marina cuando acusa a nuestro autor de precipitado y algo contradictorio. De hecho, de su recorrido histórico «sobre la naturaleza de las Cortes de España» es difícil concluir una postura clara respecto a cuándo empezó a producirse la perversión de la institución en su calidad de representación nacional y en su capacidad de maniobra política. Por una parte, es cierto que Canga participa de la idea, ampliamente extendida entre destacados representantes de la cultura histórico-constitucional, de que la inflexión se produjo irremediablemente durante el reinado de Carlos I, con toda la carga corrosiva y desagregadora del despotismo. No queda claro, sin embargo, que lo que lamente Canga sea la pérdida de la representación compleja estamental a partir de 1538, la manipulación y mediatización creciente de que serán objeto las ciudades y su representación, o ambas cosas a la vez. La indefinición no es baladí, estando en juego, como puede suponerse, una propuesta política que derivase de una concreta lectura histórica. Efectivamente, en un caso se derivaría una lectura favorable de esta constitución estamental como verdadera representación "nacional» equilibradora, en una perspectiva próxima a Jovellanos; en el otro, por contra, estaríamos en presencia de una perspectiva municipalista mucho más próxima a la postura de un Martínez Marina.

Sin embargo, para que esto último pudiera afirmarse con ciertos visos de verosimilitud, nuestro autor debería coincidir en la apreciación favorable de otros extremos, tales como la alianza entre monarquía y ciudades, expresión de un auténtico "pacto nacional» pergeñado entre los siglos XI-XII. No es ese el caso, al menos en las Observaciones. La auténtica «representación nacional», adornada, además, de una innegable capacidad legislativa parece agotarse para Canga en el siglo XI. Destruido el trono de los godos, las mismas costumbres y los mismos procedimientos de sus Juntas nacionales continuaron bajo «los Concilios de Oviedo, de Jaca, de León y de Coyanza, celebrados en los siglos IX y X». A partir de ese momento, el declive parece ya imparable: 
«El engrandecimiento sucesivo que tomó la monarquía por efecto de las conquista varió la naturaleza del gobierno y la constitución de las asambleas, las quales desde que se dixeron Cortes, perdieron el alto grado de supremacía que habían tenido en otros tiempos».

Si, por una parte, es cierto que el engrandencimiento de la nobleza y del clero fue un factor de oscurecimiento de los reyes, la alianza de éstos con las ciudades no parece que supuso la reconstrucción sobre nuevas bases de la representación nacional. Los monarcas, «empeñados en realzar su poder», fueron los únicos beneficiados, incluso a costa de las ciudades. Después vendría el siglo $\mathrm{XVI}, \mathrm{y}$ «las guerras intestinas de las comunidades, a las quales siguieron las derrotas, las cadenas pesadas que se echaron sobre el pueblo, y la ruina de la representación nacional» (p. 41); pero se trataba nada más que de la culminación de un proceso que parece anunciarse ya en los primeros siglos de las monarquías cristianas, precisamente cuando el proceso de conquista del territorio ocupado por los árabes pareció desencadenar una auténtica subversión en el mecanismo constitucional y en los procedimientos de configuración de los distintos «cuerpos» o estamentos nacionales. Ése, sin embargo, como sabemos, sería el momento escogido por Marina para situar los orígenes de una auténtica

«revolución política por la que el pueblo fue llamado al gobierno y a tener gran parte en la representación nacional (...): el clero y la nobleza perdieron las facultades que se arrogaban de turbar el estado, y su altanería se estrellaba contra el baluarte de la autoridad municipal: las ciudades y pueblos salieron de la esclavitud, sacudieron el yugo de la tiranía, comenzaron a disfrutar las dulzuras de la sociedad y a ser libres e independientes sin más sujeción que a la ley»?.

Diríase que en la perspectiva histórico-constitucional de Canga Argüelles se va consolidando, de manera realmente progresiva, una visión desagregada y desestamentalizada de la representación nacional en la que la razón política acabará por imponerse a su razón bistórica. Si nos colocamos en la perspectiva de su posterior obra, Reflexiones sociales (1811), las coincidencias con el posterior Marina de la Teoría parecen acentuarse. En ella, efectivamente, Canga lleva a sus últimos extremos la capacidad de reconstrucción de un pacto originario y nacional entre la monarquía y el pueblo como reacción frente al proceso de estamentalización de los cuerpos privilegiados y de su «apartamiento» progresivo del cuerpo nacional. En las Observaciones, aunque no muy desarrollado este punto de vista, sí que se apunta al final de la obra:

«Pues que la calidad sóla del individuo de la sociedad es la que da un derecho para contribuir con su voto a las asambleas representativas, estas deberán constar

7 Martínez Marina, F.: Teoría de las Cortes (1813), Madrid, Editoria Nacional, 1979, Vol. I, pp. $240-241$. 
de sola la clase del pueblo. Los estamentos de la nobleza y del clero han entrado en ellas en los siglos del orgullo feudal, en los quales el clero y la grandeza tuvieron más fuerza que el soberano, adquirieron riquezas y vasallos, y formaron intereses separados de los del pueblo» (p. 75)8.

Sin embargo, ni en un caso ni en el otro, el resultado será nunca contemplado desde una perspectiva corporativista en que las ciudades pasasen a constituir una auténtica representación nacional. Aceptado y constatado el proceso histórico-jurídico de la estamentalización y más o menos explicitada la teoría del «alejamiento» del cuerpo nacional de los estamentos privilegiados, cabía, efectivamente, una solución como la de Martínez Marina que erigiese a las ciudades y al "pueblo» en las protagonistas de esa auténtica revolución política, origen del pacto con la monarquía que daría forma y consistencia a la constitución de la nación, erosionada posteriormente por siglos de despliegue del despotismo. No sería ésta exactamente la solución de Canga. Su crítica al despotismo, visible en la estructura política nacional desde la llegada de Carlos I, no se resolverá en una añoranza de la pérdida de la vieja representación estamental trinitaria, porque su perspectiva es básicamente antiestamental; pero tampoco implicará esto una lectura municipalista de esa misma constitución, por mucho que algunas teorías del "alejamiento" y desagregación del cuerpo nacional de los intereses de los poderosos bien podrían inducir a ello.

Por otra parte, la crítica a la solución "política» que representa la constitución josefina de Bayona dimana tanto de sus insuficiencias para solucionar los abusos que el paso del tiempo ha introducido en las instituciones españolas, cuanto de su carácter extranjero. No deja de ser irónico para nuestro autor que lo que se presenta como «resultado de las luces francesas... (y) como el dechado de la política, y el medio de cortar los abusos» se atenga tan poco a una razón política capaz de desembarazarse de los abusos que la historia ha ido consolidando. El camino ha resultado infructuoso, toda vez que, a mayor abundamiento, supone, por su propia naturaleza y gestación, un descrédito a «nuestras antiguas fórmulas». Si se nos ofrecen unas Cortes «más viciosas que las que hasta aquí teníamos», ¿̇para qué necesitamos - argumenta Canga- «del apoyo francés para corregir las que nos han dexado nuestros mayores, y cuya energía se ha enervado por el despotismo, por la ignorancia, y por la caducidad, que cunde en todos los establecimientos?» (p. 69). Toda su crítica trasluce, en este caso, la imposibilidad radical de asumir, desde el horizonte cultural y político de una guerra de liberación nacional, cualquier presupuesto doctrinal que no estuviese legitimado en una tradición, por mucho que su relectura desembocase en

8 Las cursivas son mías. En una nota aclaratoria de esta idea, el mismo Canga escribe: «¿Y qué ventajas ha producido la concurrencia de estamentos? Resistir las instancias del pueblo quantas veces han estado en contradicción con sus privilegios, y siguiendo en sus ideas de engrandecimiento, no omitir medio para llevarlas a colmo. QQué tristes y vergonzosos documentos nos conserva la historia de esta verdad!» (p. 76)

Hispania, LXII/1, núm. 210 (2002) 113-140 
unos presupuestos similares a los combatidos. Era, sin duda, otra de las razones últimas del papel de la historia en un contexto de marcada razón política9.

Un aspecto preocupa especialmente a nuestro autor de la propuesta que viene de Bayona: el cáracter mixto de la representación nacional en las Cortes, mucho más próxima a una estructura corporativa que a una individualista y homogeneizadora, basada en la simple, pero radical condición, de «individuo de la sociedad». El «cuerpo» - no en su reminiscencia organicista, sino en tanto que elemento extraño y diferenciador respecto a una estructura superior abarcadora - se aviene mal con «la masa principal». Pese a ciertas andanadas "populares», nuestro autor está lejos de una igualitarismo económico o social; las clases sociales pueden y deben admitirse al formar parte del orden natural de la sociedad, pero el orden político sólo puede contemplar la condición de miembro de esa misma sociedad, portador de unos derechos universales y de unos deberes que le permiten, precisamente, su condición de ciudadanos activos. Para Canga Argüelles, el Canga radical de estos años, guerra y tributo, o, si se prefiere, defensa y trabajo, definen el perfil de ese ciudadano portador de soberanía. La universalidad del tributo será, en cualquier caso, una prolongación de la universalidad esencial del trabajo y del derecho a su producto; mientras que el derecho de defensa (que se traduce en la figura del ciudadano en armas) dimana del irrenunciable derecho a la defensa de unos derechos naturales y, por ende, universales. Bellos tópicos de un primer liberalismo con reminiscencias republicanas por lo que hace a la concepción y virtudes del ciudadano que alcanzarán incluso mayor categoría literaria en su obra Reflexiones sociales.

Por lo que hace a las Observaciones, el mejor Canga Argüelles, el que todavía es capaz de juntar la capacidad de ingeniería social y política con una defensa apasionada de la política como ámbito de defensa de los derechos individuales y naturales, se despliega en las páginas dedicadas a concretar su propuesta de representación nacional, pues no otra cosa está debatiéndose a propósito de las Cortes. Son las páginas que mejor enlazan, formal y sustantivamente, con el Canga de las Reflexiones sociales.

El derecho de representar a la nación depende de la sola y radical condición de miembro o individuo de la sociedad, privilegio del que deben quedar excluidos los condenados por algún delito, los que carezcan de una ocupación útil al público, hacendados que no acrediten emplearse en bien de ese público o aquellos que llegados a la edad de treinta años sigan célibes. En una palabra, «a todos aquellos, o viciosos o parásitos, que sacan del estado la susbsistencia sin retribución alguna» (p. 74). La nación en la que está pensando Canga Argüelles es una nación de trabajadores útiles y de contribuyentes; ni el ocio ni el

\footnotetext{
9 Respecto a esta coyuntura de la guerra de la independencia como amalgama de actitudes y propuestas divergentes que condicionó y limitó el horizonte de formulación y despliegue de cada una de ellas, vid. Álvarez JUNCO, J.: «La invención de la guerra de la Independencia» en Claves de razón práctica, (Madrid), 67 (1996), pp. 10-19.
} 
privilegio otorgan derecho a la representación. De nuevo el trabajo y el tributo se constituyen en los dos elementos básicos, principio y fin de una cadena que, por un lado, une al hombre en sociedad desde su más primigenia universalidad y naturalidad, y, por otro, le convierte en un ciudadano activo. El interés (individual $\mathrm{y}$, en tanto que individual, colectivo o nacional) se erige en el eslabón intermedio que, al tiempo que integra en el conjunto nacional y/o social, se erige en criterio discriminador de aquellos que, voluntariamente, han quedado excluidos de esa cadena. Es desde esa perspectiva antropológica del bombre interesado desde la que creo que hay que interpretar su propuesta de excluir a los célibes, ya que «el hombre que no procura dexar sucesor» carece «de tan podereosos estímulos» $(\text { p. } 75)^{10}$.

La representación nacional debe constar de «sola la clase del pueblo», entendiendo aquí el concepto de clase a efectos políticos y no sociales. Históricamente, de ese conjunto uniforme desde el punto de vista de los derechos y de los deberes, quedaron excluidos los estamentos de la nobleza y del clero que «en los siglos del orgullo feudal» adquirieron riquezas y vasallos, y formaron intereses separados de los del pueblo» (p. 75). La idea de la separación y exclusión de los estamentos privilegiados del cuerpo principal de la nación actuará así, en Canga, como contrapunto negativo del mundo de las pasiones interesadas que pueden concurrir a la defensa del bienestar de la nación.

Bajo estos presupuestos, presididos todos ellos por el sentido unitario e integrador de "pueblo», sólo era posible una representación nacional en las Cortes "proporcionada a la población del reyno», principio realmente disolvente de «cuerpos» o estamentos diferenciadores que, no obstante, como tendremos ocasión de ver inmediatamente, no impide en nuestro autor la construcción de una peculiar geografía y sociología de la representación nacional, contenedora de ciertas instancias intermedias y mediadoras entre la voluntad general de la nación y los intereses más particulares y concretos de sus individuos. Efectivamente, Canga propone la proporción de un diputado por cada cien mil habitantes, siendo la Provincia la circunscripción electoral sustantiva y articuladora de toda la representación. Su punto de partida, ya lo hemos visto, apunta hacia una solución individualista desagregada, pero el mismo se resuelve en el peso sustantivo de determinadas instituciones intermedias, en este caso la Diputación. Los procuradores de Cortes «son unos apoderados de las provincias que los envían, deberán estar unidos con ellos» y «no podrán salir de las instruccio-

10 No obstante, es cierto que también puede interpretarse la propuesta de exclusión de los célibes como una medida contra el clero. En cualquier caso, no parece una interpretación excluyente en relación a la más amplia de la perspectiva antropológica. Para esta última, en general, desde una perspectiva de historia de las ideas, HirSchMan, Albert O.: Las pasiones y los intereses. Argumentos políticos en facor del capitalismo previos a su triunfo, Barcelona, Península, 1999 (edic. original en inglés de 1977); en el mismo sentido, el extraordinario y sugerente libro de DíEZ, F.: Utilidad, deseo y virtud. La formación de la idea moderna del trabajo, Barcelona, Península, 2001. 
nes que se les dieren sin su anuencia» (p. 86). Anteriormente había afirmado que a los mismos

«se les les exigirá un juramento solemne de hacerse bien sus funciones, y de entenderse siempre con la diputación de la provincia, manteniendo con ella una correspondencia seguida para que ésta tenga conocimiento de los que se trata» ${ }^{11}$.

Es así cómo, desde la parroquia hasta la capital de provincia, pasando por la cabeza de partido, se establece una geografía contenedora de una peculiar perspectiva sociológica que, en el plano de la representación política, tiene como punto de partida a la familia y a su representante, y finaliza en una Nación concebida como una gran familia con un padre-monarca a su cabeza, pasando - $\mathrm{y}$ este me parece un dato sustancial- por ese eslabón intermedio que es la Provincia y su órgano de representación, la Diputación. El peso sustantivo de todo el organigrama político recae en esta instancia intermedia, capaz de una doble función que se antoja de primordial importancia en el contexto político en el que se formula: servir de freno al peligro de un despotismo corrosivo y siempre acechante, y que se supone mejor contenido por esta «cuerpo» intermedio que por una suma desagregada de inviduos portadores de soberanía; pero, al mismo tiempo, en tanto que instancia política, resultar un perfecto reflejo de aquellos intereses sociales y económicos componentes de la sociedad. Si el pensamiento constitutivo de la sociedad en Canga Argüelles tiene un arranque individualista y iusnaturalista, y configura un sujeto portador de derechos universales, la resolución de la sociedad política desemboca en él en una perspectiva también homogénea y unitaria de una nación y de un pueblo, pero donde los mecanismos representativos, aunque no se articulen ya a partir de la antigua perspectiva corporativista y estamental, tampoco se resuelven en una perspectivia individualista desagregada, sino perfectamente agregada y estructurada en torno a la comunidad-familia y en torno a la comunidad-provincia. Se trata de una propuesta que nos conduce, como línea de reflexión, al papel de determinados «cuerpos intermedios» como diques necesarios ante la actuación despótica o arbitraria; una actuación que, a esas alturas históricas, tenía ya dos manifestaciones concretas: la del absolutismo sin límites o no reformista, y la de la perversión del mensaje revolucionario por el bonapartismo. Canga parece comulgar de esa preocupación constante en la Europa del momento por frenar el abuso del poder. De hecho, la experiencia revolucionaria francesa, por una parte, y la propia tradición política, por otra, marcan la pauta de una discurso basculante entre el pasado y las lecciones de un presente que lo mismo se manifiesta en términos de un jacobinismo contundente, como de un bonapartismo desnaturalizador. Burke, desde el campo conservador, y B. Constant, desde el liberalismo doctrinario, son un ejemplo de ese temor al abuso de poder del que par-

11 Las cursivas, de forma harto significativa, aparecen en el original. 
ticipa también Canga, aunque desde una propuesta política no reducible ni a uno ni a otro ${ }^{12}$.

El modelo político de Canga Argüelles no es un modelo de monarquía parlamentaria, sino de un claro y contundente dominio del legislativo sobre el ejecutivo, permanentemente bajo sospecha. $\mathrm{Y}$ un modelo en el que resuenan los ecos rusonianos de la ley como expresión de la voluntad general que, además se resuelve en una inmediatez entre el acto jurídico-legislativo y la voluntad individual. La figura del ciudadano-legislador se completa, en su peculiar perspectiva política, con la del ciudadano-armado, protagonista activo de una convulsión política cuando la patria fuese declarada en peligro ante alguna contravención por parte del monarca a lo resuelto por la nación:

"Quando llegase el caso terrible de faltar el monarca a lo resuelto por la nación, o a los deberes que la constitución prescribiere, la diputación general declarará la patria en peligro, llamará a Cortes para un lugar seguro, los pueblos se pondrán en estado de defensa, y una convulsión política hará entar en sus deberes a todos» (p. 104).

Es, más allá del activo papel que le concede al «cuerpo intermedio» de la Diputación, la idea presente en el primer liberalismo del derecho a la resistencia que puede llegar a la revolución y que tiene su razón de ser en la idea de que la política no legitima la tradición, sino el consentimiento de los individuos.

Debemos insistir: la articulación político-institucional que se deriva de esa peculiar formar de representarse a la nación, no se agota en el esquema bipolar Ejecutivo (fuerte, pero bajo sospecha)/Cortes (representación de una voluntad general), sino que tiene en la Diputación Provincial (poco definida en cuanto a su composición y funciones en este escrito) la piedra de crucería de toda la ingeniería política de nuestro autor. Una solución, en definitiva, que anunciaba sones de lo que luego será el edificio institucional diseñado en Cádiz y que, como afirma Portillo,

«no llegaba a sancionar sin duda ningún principio de hechura federal pero sí tomaba buena nota de la fuerte posición que las juntas provinciales habían logrado alcanzar durante la crisis de independencia con lo que se alumbraba constitucionalmente una forma de composición que otorgaba, sobre todo a las provincias, una inusitada capacidad de gestión autónoma del territorio...»13

12 Sobre Burke y Constant, por ejemplo, MaCPHERSON, C. B.: Burke, Madrid, Alianza Editorial, 1984; POCOK, J.G.A.: «Edmund Burke» en GuERCI, L. (ed): l'Albero della Rivoluzione, Turin, 1989, pp. 89-96; FURET, F.: «Burke o el fin de una única historia europea» en La revolución a debate, Madrid, Ed. Encuentro, 200, pp. 89-108; o ABELLÁN, Joaquín: «Reacciones ante la Revolución francesa (Edmund Burke, los pensadores alemanes y de Maistre y de Bonald)» en VALLESPín, Fernado (ed.): Historia de la Teoría Política, Madrid, Alianza Editorial, 1994, Vol. 5, pp. 14-81; y SÁNHEZ-MEJIA, Ma Luisa,: Benjamín Constant y la construcción del liberalismo postrevolucionario, Madrid, Alianza, 1992.

13 PORTILLO, J.M., "La historia del primer constitucionalismo español. Proyecto de investigación» en Quaderni Fiorentini (Florencia) 24 (1995) pp. 303-373, donde también se apunta la raiz 


\title{
RIBELLES O LA REFORMULACIÓN CONSTITUCIONAL DE LA MONARQUÍA DESDE LA HISTORIA CRÍTICA
}

El caso que presentamos a continuación es bastante distinto del cosmopolitismo liberal de Canga Argüelles. Bartolomé Ribelles (1765-1826), fraile dominico en el Real Convento de Predicadores de Valencia, en el que ingresó a los veintidos años, fue catedrático de Arte y Teología en la Universidad. Nombrado en 1800 por el Ayuntamiento "Cronista oficial de la ciudad de Valencia y del Reyno», desempeñó también los cargos de Bibliotecario Mayor del Convento y "Colector de la contribución diaria de los conventos del Reino de Valencia a la Cámara Generalicia». Ribelles forma parte de la amplia lista de historiadores dominicos que, desde los Anales del reino de Valencia (1613) de Francisco Diago, recorre toda la centuria dieciochesca con nombres como Jacinto Segura, José Teixidor, discípulo del anterior y de Gregorio Mayans, Luis de Galiana, Luis Sales, o Jaime Villanueva. Continuadores de los trabajos críticos del barroco español; hicieron de la historia crítica y filológica -ampliamente desarrollada por Mayans - el instrumento capaz de una regeneración cultural sobre la que sustentar una reconstruida idea de un Reino (el de Valencia, en este caso), difícilmente sustraible de unas especificidades forales-históricas, aunque no por ello antagónicas en el contexto más amplio de la monarquía hispánica. La obsesión por el documento y el criticismo filológico serán para ellos los instrumentos con los que oponerse a los fabuladores y mitómanos capaces de construir una tradición no verificada ni sustentada en pruebas fehacientes. Era una forma de reconstruir una maltrecha identidad político-cultural que resultaba ahora, no obstante, reinventada y reconducida al operar desde el supuesto temporal y político de una monarquía cada vez más generalista, uniformizadora y ejecutiva, $\mathrm{y}$, respecto a la cual, esas especificidades «regionales» se considerasen complementarias y no contradictorias ${ }^{14}$.

\begin{abstract}
ilustrada de este ámbito provincial traducido ahora en clave constitucional que, al tiempo que deja salva la indivisibilidad de la soberanía, permite una gestión más directa de los intereses económicos e individuales (p. 358); la cita del texto en p. 356. Más desarrollado por el mismo autor en Revolución de nación. Orígenes de la cultura constitucional en España, 1780-1812, Madrid, Centro de Estudios Políticos y Constitucionales, 2000. Un análisis complementario del nuevo espacio institucional de la Diputación en SANTANa Molina, Manuel, La Diputación Provincial en la España contemporánea. Madrid, I.N.A.P., 1989; Martín Retortillo BaQuer, S. y Argullol Murgadas, E., Aproximación bistórica al tema de la descentralización, 1812-1931. Madrid, 1973. Pero la perspectiva más acertada de la Diputación como garante constitucional en MuÑoz Bustillo, C.: «Los antecedentes de las diputaciones provinciales o la perpleja lectura de un pertinaz lector» en Anuario de Historia del Derecho Español (Madrid) LXVII (1997) pp. 1179-1192; y, sobre todo, de la misma autora, en «Los Otros celadores del orden constitucional: Diputaciones provinciales y ayuntamientos constitucionales» en IÑURRITEGUI, J.M ${ }^{a}$ y PORTLLO VALDÉs, J.Ma: Constitución en España: orígenes y destinos, Madrid, Centro de Estudios Políticos y Constitucionales, 1998, pp. 179-213.

14 Desde este punto de vista, es decir, desde un planteamiento constitucional de la monarquía dieciochesca, creo que está haciendo falta una relectura de toda esta historiografía crítica que, por
\end{abstract}


Ribelles, continuador de Teixidor, se encuentra al final de esta tradición, con una producción historiográfica y erụdita que, además, se inicia muy tardiamente, coincidiendo con su nombramiento como cronista oficial y cuando ya contaba cincuenta años Coincide, por tanto, con los críticos años de inicio de la centuria que enlazarán, sin solución de continuidad, con la profunda crisis constitucional de la monarquía a partir de 1808 . Hombre de archivo por sus cargos y su formación, hace alarde de ese criticismo esencial sustentado siempre en el documento. A propósito de esto, escribirá a su amigo Villanueva:

«No soy amigo de caprichos, sino de realidades: ni fio de mi dictámen quando no se halla apoyado. Presentaré a Vd. los fundamentos de mis opiniones con la misma sencillez con que existen en los preciosos manuscritos que o poseo o disfruto en la famosa Biblioteca de este nuestro Convento...»15

Su nombramiento como cronista de la ciudad y reino significará la posibilidad de conectar el método histórico y la producción historiográfica con una realidad política inmediata aunque sólo interpretable desde una peculiar razón histórica como forjadora de especificidades y de derechos.

La historia, una historia que ya no se concibe como retórica moralizante y ejemplificadora de supuestas edades de oro perdidas, sino como una historia crítica y erudita, empieza a convertirse en el instrumento aclaratorio y sustentador de unos derechos necesitados en cualquier caso, y más en la coyuntura de que se trata, de un esclarecimiento y de una legitimización. El feudalismo y su maraña de derechos consuetudinarios y adquiridos se presenta como un «territorio» sólo explorable a través del método crítico y erudito, más allá de supuestos racionalmente preconcebidos o de derechos sustentados en una teoría iusnaturalista. Más allá, en definitiva, de la política. Hacer su relectura en un momento en que esos derechos están siendo atacados o cuestionados es una

otra parte, es bastante abundante en el caso del País Valenciano. De momento, aunque especialmente centrado en la primera mitad del siglo XVIII, MESTRE, Antonio: Historia, Fueros y actitudes políticas. Mayans y la bistoriografía del XVIII, Valencia, Ayuntamiento de Oliva, 1970. También, MANTULLI, Roberto, «L'ús de la crítica en els escrits de l'historiador català Joan Francesc de Masdeu» en Recerques (Barcelona) 11 (1981) pp. 137-148; y BATLLORI, Miquel: Història, Classicisme i Filosofia al segle XVIII: Gustà, Pou i els Masdéu, Valencia, Edicios Tres i Quatre, 1998. La misma función de la historia como terreno político en el que dirimir el nuevo espacio provincial vasco en el contexto del absolutismo de final de siglo, en PORTiLLo, José $\mathrm{M}^{\mathrm{a}}$ : Monarquía y gobierno provincial. Poder y constitución en las Provincias vascas (1760-1808), Madrid, Centro de Estudios Constitucionales, 1991, especialmente pp. 170-204.

Sobre Ribelles, ESPONERA CERDÁN, A.: «La escuela historiográfica del convento de predicadores de Valencia en el siglo XVIII" en AA.VV. (eds): ¿Qué es la bistoria de la Iglesia?, Pamplona, Edic. de la Universidad de Navarra, 1966, pp. 397-420. Agradezco a Fr. Alfonso Esponera (O.P.) el haberme proporcionado referencias bibliográficas sobre este autor $y$, sobre todo, el haberme facilitado el acceso a los fondos del archivo del actual Convento de Predicadores de Valencia.

is Archivo del Real Convento de Predicadores de Valencia (ARCPV), ms. 81, p. 851. 
obligación que se impone por encima de encargos e intereses concretos: es una forma de pensar una constitución y una patria que sólo resultan comprensibles como contenedores y sustentadores de esos derechos. Es desde estas coordenadas y desde esta perspectiva histórica desde la que cabe calibrar su aportación al debate preconstitucional, concretada en una de las pocas obras suyas editadas en su momento: las Memorias histórico-críticas de las antiguas cortes del Reyno de Valencia, incluida dentro del expediente instruido por la Audiencia de Valencia en respuesta a la circular de 24 de junio de 1809 de la Comisión de Cortes de la Central ${ }^{16}$.

La recepción de dicha circular por el alto organismo judicial valenciano fue seguida del nombramiento de una comisión encargada de recoger las noticias pertinentes y elaborar el informe que debería, en su caso, representar la postura oficial de la Audiencia respecto al tema de Cortes. Fueron elegidos al efecto los oidores D. Vicente Joaquín Noguera, D. Manuel Mahamud y D. Ramón Giraldo de Arquellada. Rápidamente quedaron delimitados los perfiles por los que estos oidores y la propia Audiencia iban a encauzar el encargo de la Central. Era difícil no hacer una lectura en clave histórica, ya que «esta provincia se gobernó por Leyes Forales hasta la sucesión del señor Felipe $\mathrm{V}$ en el Trono de España». De hecho, los oidores pronto se entregaron a un trabajo archivístico, más que a un trabajo de reflexión teórica, sirviéndose de los fondos del Archivo de la Baylía General y del Real Patrimonio. La recopilación de noticias y datos era el único camino de activar una estructura constitucional que, en ningún caso era entendida como un simple ordenamiento jurídico-político, sino como un conjunto institucional articulador de prácticas, derechos y rentas. Desde esta perspectiva, las Cortes, las tradicionales en este caso, no eran más que una pieza de un edificio más amplio destinado al equilibrio de los distintos intereses en juego, en concreto aquellos que representaba el Reino y los que representaba el Rey.

Fue a la altura de septiembre cuando la comisión se puso en contacto con el P. Bartolomé Ribelles, "porque sabíamos su mucha afición a la Historia antigua del Reino y su grande instrucción en la materia», solicitándole una informe al respecto. El estudio del dominico estaba concluido en diciembre y el impacto que causó debió ser harto favorable:

16 Memorias histórico-críticas de las antiguas cortes del Reyno de Valencia. Escribialas el P.M. Fr. Bartolomé Ribelles del Real Convento de Predicadores, y Cronista de la Ciudad y Reyno de Valencia, Valencia, año de 1810, 100 pp. (cito por la edic. facsímil de Librería París-Valencia, 1996). El original se encuentra en A.R.C.P.V., ms. 72, pp. 563-651. El expediente remitido por la Audiencia de Valencia, que contiene, a su vez, las Memorias de Ribelles, en Archivo de las Cortes (AC), Leg. 1, exp. $\mathrm{n}^{\circ}$ 63. Parte del mismo está publicado en Cortes de Cádiz. I. Informes oficiales sobre Cortes. Valencia y Aragón, Pamplona, Ediciones de la Universidad de Navarra, 1968, pp. 25-73, donde se reproduce el informe del fiscal en lo civil, pero no el escrito de Ribelles. Agradezco a J.M ${ }^{a}$ Portillo el haberme proporcionada el material relativo al expediente de la Audiencia de Valencia existente en el Archivo de las Cortes.

Hispania, LXII/1, núm. 210 (2002) 113-140 
«Nos dedicamos inmediatamente a examinarlo y encontramos que debíamos suspender nuestros trabajos, pues era imposible dar al asunto más instrucción, ni hacer mejor elección de ideas y pensamientos que los que se hallan en las citadas Memorias...(y) hemos resuelto adoptar como Informe nuestro, el papel del Padre Maestro Rivelles y dirigirlo bajo este concepto al Real Acuerdo».

El expediente instruido por la comisión de oidores pasó a examen de los fiscales, produciéndose en este caso una clara disimilitud: el fiscal del crimen se adhirió en todos los términos al sentir de los oidores, mientras que el fiscal de lo civil, Francisco Tomás de los Cobos, emitió un dictámen propio, de sesgo bastante distinto al que representaba la memoria de Ribelles. No obstante, la Audiencia no se pronunció sobre uno u otro y el pleno del tribunal se limitó a elevar a la Central el conjunto del expediente. Puede afirmarse, por tanto, que en el seno de la Audiencia de Valencia se dieron dos opiniones respecto al problema constitucional y a la representación en Cortes: la más histórica que representan las Memorias de Ribelles y que fue adoptada como propia por Noguera, Mahamud, Giraldo y el fiscal del crimen; y la que representaba el fiscal Francisco Tomás de los Cobos, menos «regionalista». y, tal vez por ello, difícil de ser aceptada por el conjunto de los miembros del tribunal.

Las Memorias de Ribelles suponen uno de los ejemplos más nítidos de confluencia entre la historia crítica y la búsqueda de un proyecto constitucional entendido a partir de una tradición necesariamente recuperada y reinterpretada desde el supuesto de un perfecto equilibrio entre el Rey y el Pueblo (Reino). La patria valenciana es por ello el conjunto de los derechos representados estamentalmente y del respeto constitucional a los mismos. Hay un punto de arranque que tiene que ver con el origen de las Cortes y su naturaleza, entendiéndose esta cuestión como de primordial importancia pues, en función de la respuesta dada, se condicionará en un sentido o en otro la trayectoria constitucional del Reino. No es lo mismo suponer un arranque de la historia del Reino sin la celebración de unas Cortes y con la consideración de los Fueros como de donación regia, que entender estos últimos como un acto pactado y celebrado en Cortes. A nadie se le escapa que lo que está en juego en esta disyuntiva es la la acentuación o no de la capacidad despótica del monarca en menoscabo de los derechos del Reino. Ribelles es muy explícito al respecto:

«El primer congreso de esta naturaleza (Cortes) se celebró antes del año 1240. Porque se equivocó mucho D. Joseph Villarroya <teniendo por cosa indubitable, que el Rey D. Jaime el Conquistador no celebró Cortes a los Regnícolas del Reyno de Valencia $>$. Este es uno de aquellos extravíos, que más pueden perjudicar en el dia a los derechos primordiales y legítimos de los Valencianos» (pp. 4-5).

Por tanto, la larga disquisición histórico-crítica a que se entrega el dominico sólo adquiere sentido desde la perspectiva de un presente inmediato en el que se saben en juego unos derechos primordiales. También se equivocó, en este

Hispania, LXII/1, núm. 210 (2002) 113-140 
sentido, el jurisconsulto del siglo XVII, Lorenzo Matheu y Sanz, quien alegó dos razones para excluir a los primeros Fueros de la clase de Leyes paccionadas: «La primera fue, que no se celebraron Cortes al tiempo de la formación de los Fueros; la segunda, que en este solemne acto no hubo oferta alguna de dinero, por cuyo medio se cerrase el contrato, y se hiciesen leyes irrevocables». Ambas razones, según Ribelles, «carecen enteramente de subsistencia y de verdad; pero ambas necesitan de una larga discusión, para que se vea la falta de conocimientos históricos que las produxo» (p. 6). Difícilmente puede establecerse una conexión más clara entre historia-derechos-constitución.

La línea argumental desplegada por el predicador tiene una serie de ideas matrices bastante nítidas a través de las cuales queda patente la oposición a aquellos tratadistas que tendieron a interpretar la historia constitucional desde una perspectiva más patrimonialista y, por tanto, más erosionadora de los intereses adquiridos. En el texto, como ya hemos visto, se critica especialmente a Lorenzo Matheu y Sanz y a José Villarroya, ambos interpretables desde un cierto neoforalismo finisecular a partir del cual intentar, no obstante, una readecuación de la estructura constitucional del reino o de la provincia en la general de la monarquía. En contra de ellos, varias serán las ideas a defender a través de un exhaustivo análisis crítico de textos y documentos: que los Fueros del Reino se establecieron y acordaron en Cortes; que la representación que hubo en esas primeras Cortes correspondía a «toda la extensión» del «pueblo valenciano", es decir, «a los tres Estados, Eclesiástico, Militar y Real»; y que, en consecuencia, el resultado de tal acto es "naturalmente» un «ajuste, convenio o contrato entre el Rey y los representantes del Reyno, cuyo resultado fueron nuestras primeras leyes paccionadas» (p. 25).

En la mente de Ribelles no cabe otra consideración que la que se deriva de ese caracter paccionado como arranque del edifico constitucional valenciano. $\mathrm{La}$ manida idea del «derecho de conquista», tantas veces argüida en la tradición literaria y foral para justificar las preeminencias de un rey que, por eso mismo, recibe el título de «El Conquistador», parece invertirse en su caso a favor precisamente de los fueros y libertades de los que ayudaron al monarca en la conquista del reino. Los repobladores, «todos...Aragoneses o Catalanes»,

«habían cooperado, no menos que el Rey, a la conquista; y no puede concebirse que un Rey justo y liberal, no menos que agradecido, les diese en recompensa un despojo fatal de sus anteriores derechos, y una degradación que rayase en los términos de la más dura servidumbre» (p. 25).

El resultado se deduce de la misma naturaleza de las premisas: la estructura constitucional valenciana en sus orígenes se distingue por un equilibiro entre el poder del Rey y el del Reyno, auténtica salvaguarda de cualquier tentación despótica. La idea de equilibrio, sin embargo, no sólo define la relación entre el Reino colectivamente considerado y su cabeza, el Rey, sino que sirve también de elemento rector y definidor de los equilibrios estamentales y corporativos en 
el seno mismo del Reino. No se trata sólo de que éste se piense desde la representación estamental tripartita, siempre presente, según Ribelles en todos los actos en Cortes, sino de una peculiar historia y visión de cada uno de sus componentes que, caso de augurar algún tipo de preeminencia, sería en favor de las ciudades y villas reales. Efectivamente, la admiración de Ribelles hacia los Consejos Generales de las villas y ciudades de realengo, con representación en Cortes, constituye uno de los rasgos distintivos de sus Memorias. Estos auténticos «señoríos», de amplia jurisdicción sobre su término, supieron en muchos momentos ser el freno al anhelo desmedido de «barones y títulos». Auténtico contrapeso al "yugo feudal», debían su pujanza, en buena lógica, a la permanencia de las jurisdicciones y derechos del Real patrimonio por cuya integridad y reintegro de jurisdicción enajenadas siempre lucharon. Estas auténticas "repúblicas", gobernadas por los «probi homines», constituyen, de hecho, el esqueleto de la constitución valenciana. No puede deducirse de ello una lectura antiseñorial de la historia y de la constitución valenciana, sino, en todo caso, una muestra de los contrapesos de intereses que la conformaban y una mejor predisposición, por su estructura y naturaleza, de las corporaciones realengas a representar los intereses más generales por encima de los particulares. En cualquier caso,

«no es esto decir, que los Barones y Títulos del Reyno jamás procuraron el bien de sus vasallos, sino que atendieron con mayor eficacia a los intereses propios, que a los de sus clientes, aun quando parecían abogar a favor de estos» (p. 56).

No hace falta forzar demasiado la lectura del texto del dominico para llegar a la conclusión de que el Real Patrimonio subyace en toda su argumentación constitucional. Es, con todo, un patrimonio regio transmutado en el usufructo de derechos y regalías y en la preeminencia jurisdiccional de las ciudades realengas. Estamos, por tanto, lejos de la preeminencia patrimonialista de la Corona en que lo convirtieron algunos tratadistas, y nos acercamos más a su consideración como plataforma desde la que entender el reforzamiento del ámbito específico del Reino; un Reino que nunca se entenderá desde una perspectiva uniformizadora, sino desde la diferenciada de los distintos estamentos que lo configuran y sus diversos intereses en juego. Entre el Rey y el Reino, Ribelles parece optar por el segundo, por mucho que en un momento determinado afirme que «unos y otros estaban convencidos de que ni el Rey solo, ni los Brazos solos podían hacer leyes, sino todos juntos por medio de un ajuste y convenio recíproco» (pp. 25-26).

Consejos Generales, Parlamentos y Cortes constituyen para Ribelles el esqueleto institucional de un Reino que, a lo largo de siglos, supo, pese a la degradación, mantener ese nivel de representatividad y de preeminencia ante al aumento del poder despótico de los monarcas. También la degradación que se dejó notar en Castilla, se sintió en el Reino de Valencia «desde la época de la Unión de las dos Coronas». Pero las diferencias siguen existiendo, ya que «ni fueron $\tan$ fu-

Hispania, LXII/1, núm. 210 (2002) 113-140 
nestos los estragos, ni tan executivo el contagio degenerador». Era, suavemente expuesto, la gran diferencia observada entre un Reino cuyo recuerdo constitucional nunca llegó a extinguirse y aquel otro en que dicha estructura había sido violentada y erosionada por los efectos del despotismo. Adoptar como modelo de la representación nacional la que se deduce del funcionamiento y carácter de las Cortes valencianas era apostar por un proyecto en el que «se hallaban puestos en perfecto equilibrio el Rey, y el Pueblo; el señorío y el vasallage; la nobleza y los ciudadanos; la opulencia y la escasez; la justicia y la subordinación...» (p. 99). Era Valencia y no Castilla el modelo a seguir.

\section{BORRULL O LA ILUSTRACIÓN AL SERVICIO DE LOS DERECHOS ADQUIRIDOS}

La trayectoria personal y profesional de Francisco Javier Borrul y Vilanova (1745-1837) está todavía por reconstruir, así como su significado en el contexto político e ideológico valenciano de finales del siglo XVIII y primer tercio del XIX. La ausencia de historigorafía en este caso resulta especialmente incomprensible al tratarse de uno de los más inteligentes constructores del primer pensamiento antiliberal valenciano. Basado en la tradición foral y patrimonial del Reino, tímidamente apuntada ya en el historicismo criticista de Gregorio Mayans, será un pensamiento que enlazará, sin solución de continuidad, con el momento de debate constitucional de principios del XIX, y se convertirá en sus manos en un denodado esfuerzo por la conservación de determinadas «peculiaridades» de la formación valenciana en el contexto de un nuevo estado liberal. Amigo personal de Gregorio Mayans y de Francisco Pérez Bayer, es posiblemente, según opinión expresada por Manuel Ardit, el último representante de la gran generación ilustrada valenciana. Historiador, erudito y jurista, ejerció de abogado, obtuvo varios cargos en la Real Audiencia de Valencia y fue secretario del secreto del Santo Oficio y catedrático de derecho civil en la universidad de Valencia (1774-1779), a cuya institución pasó su espléndida biblioteca.

Su obra más famosa, al menos la más conocida, es la que nos interesa comentar aquí, dada su coincidencia e incidencia en el debate preconstitucional: Discurso sobre la constitución, que dió al reyno de Valencia su invicto conquistador el Señor D. Jayme Primero, de $1810^{17}$. El cuerpo fundamental del texto sorprende por su disposición moderna, con tres partes netamente diferenciadas en las que se trata, respectivamente, del «Poder legislativo», del «Poder executivo» y del «Poder judicial», con una estructura que pronto se adivina, no obstante, como reflejo de una lectura más próxima al Montesquieu diseñador de una monar-

17 El título completo es Discurso sobre la constitución que dió al Reyno de Valencia su invicto conquistador el Señor D. Jayme Primero, por Don Francisco Xavier Borrul y Vilanova, juez de diezmos, primicias y tercios-diezmos de dicho Reyno, Valencia, en la imprenta de D. Benito Monfort, 1810. Cito por la edición facsímil de la librería París-Valencia, 1992. 
quía con equilibrio de poderes que a la separación de poderes dimanantes de una perspectiva más netamente liberal. Se acaba con un interesante estudio comparativo de las constituciones castellana, de la de Bayona, francesa e inglesa respecto a la valenciana.

El punto de partida de Borrull es netamente antiabsolutista, por lo que esta formación política significa para él de mero y simple despotismo. Es el mismo grito forjado en un espacio común de crítica a una monarquía sin límites, pero con posibilidades, como sabemos de proyectos alternativos a la hora de superar su desbordante y «desaforada» acción política: o se culmina esa directriz política con tal de establecer nuevo escenario y nuevos sujetos de soberanía; o, por el contrario, retornamos a una tradición y a una concepción de lo político donde el lenguaje judicialista se convierte en expresión máxima de una política que, en consecuencia, sólo tiene sentido como salvaguarda de los derechos, de las «constituciones» y de los «fueros» que ese mismo lenguaje se ha encargado históricamente de ir construyendo y delimitando. La postura de Borrull, lógicamente, está más próxima a la segunda solución que a la primera, sin que ello signifique, al menos a priori, su decantación por una solución burdamente tradicionalista o reaccionaria, sino más bién un inteligente esfuerzo por insertar el «derecho de los Reinos» (de uno, en su caso: del de Valencia) dentro de un horizonte más amplio, inevitablemente puesto al descubierto con la crisis constitucional y de poder de principios de siglo. Su proyecto en este sentido, aun partiendo de la misma tradición histórico-crítica de la Ilustración de un Ribelles, es mucho más global y de más amplio alcance que el del dominico. A ello debió contribuir en no poca medida la mayor y más amplia formación jurídica de Borrull, lo que lo convierte en una de las voces privilegiadas en un momento de crisis constitucional e histórica, precisamente en el mismo momento en que ese lenguaje y esa larga tradición cultural y política puede convertirse en un puente de determinados derechos hacia un horizonte más amplio y reconstruido de salvaguarda de un sentido de la propiedad, no entendida ni aquí ni ahora como dimanante de una configuración universalista y uniformizadora de la sociedad, sino como diseñadora de concretos particularismo políticos y de naturales jerarquías sociales.

Desde el principio, empezando por el propio título de su obra, queda meridianamente claro en la intención de Borrull la responsabilidad atribuida a Jaime I en el «arreglo de la legislación de este reyno». Inicialmente, en un momento germinal, el binomino rey-reino no connota ningún tipo de dualismo irreductible en sus caracteres, al presentarse el segundo elemento como una prolongación patrimonial del primero. Esa característica queda establecida desde el primer momento como clave interpretativa de todo su discurso. Es, no obstante, una clave que conviene matizar para diferenciarla, en su caso, de puntos de partida similares. La concepción patrimonial del reino por derecho de conquista, efectivamente, es un lugar común que podemos considerar también implícito en Ribelles. Pero se trata de un presupuesto que no asegura un 
idéntico desarrollo ni un similar punto de llegada. La postura del dominicio, empeñado también, al igual que Borrull, en una lectura no despótica de la capacidad del monarca, se traducía en la insistencia de los Fueros como leyes paccionadas y establecidas en asambleas que, sin discusión, podían ser consideradas como unas cortes que albergaban la representación de los tres estamentos del reino. Sólo la presencia de los intereses de terceros, estamentalmente representados, al lado de Jaime I, puede suponer para el religioso un freno a esa interpretación despótico-patrimonialista que se puede derivar del origen histórico del reino. De ahí su insistencia en la crítica a los tratadistas barrocos o tardo ilustrados empeñados en una lectura realista no paccionada de los Fueros o en la negación del carácter de cortes a las primeras asambleas.

La crítica de Borrull a estos tratadistas, particularmente a Matheu y a Francisco León (ya que Villarroya no aparece en su horizonte discursivo), se desenvuelve por idénticos derroteros. Es la lectura supuestamente «despótica» que se hace de la capacidad del monarca, concretada tanto en la capacidad de abolición de los Fueros, cuanto, sobre todo, en la negativa de la capacidad legislativa a las Cortes y, por tanto, al Reino, la que está también en el centro de su crítica. Sin embargo, el núcleo de la discusión no estará para él en si los Fueros adquieren el carácter de ley paccionada o no, aspecto éste que le parece de segundo orden: el punto de partida patrimonial de Borrull tiene una sentido casi germinal y constitutivo, encontrándose en él el origen de una cesión voluntaria de parte de los poderes constitutivos de la soberanía. Establecido un «Código de Fueros» y formada "la Constitución de Valencia», gracias a un acto de libre disposición patrimonial del monarca conquistador-legislador, queda fijada la organización política del reino a partir de dos principios que se convertirán, ya desde este momento, en incuestionables e irrenunciables: los «límites de la jurisdicción real «y «la conservación del patrimonio de los que soportan todas las cargas del Estado" ( $\mathrm{p} 2$ ); es decir, una monarquía con límites y una monarquía que supusiese el respeto a los derechos patrimoniales de terceros, léase del Reino.

El punto de partida patrimonialista de Borrul no conduce en absoluto (tampoco en Ribelles), a una monarquía más expeditiva o ejecutiva. Es el suyo un patrimonialismo originario y constitutivo que se encuentra en la base de la cesión voluntaria por el monarca de parte de la soberanía, estructurando una organización social y política en la que ese patrimonialismo pueda y deba extenderse a otras clases del estado. No estamos tampoco en presencia de una vía patrimonialista a posteriori, definitoria de determinados absolutismos y desde la que reconstruir y reordenar el espacio de la corona en tanto que espacio común y general en contra de particularismos y estamentalismos, como podría ser el caso de Canga Argüelles. Es un patrimonialismo inicial y esencial, definitorio también de otros espacios políticos y de derechos y, en consecuencia, suponiendo la pluralidad de esos espacios en un equilibrio que comporta, necesariamente, una monarquía con límites y una defensa, tanto del patrimonio regio como de los patrimonios particulares o estamentales. Es una propuesta muy alejada, 
en definitiva, del «universalismo administrativista» que se le supone tanto al absolutismo como a una determinada perspectiva patrimonialista a él unida; implicará, por supuesto, similar o más rotundo rechazo al «universalismo político» de determinadas propuestas liberales; y supondrá, por contra, la defensa de un orden ya constituido y estructurado a partir de particularismos y derechos adquiridos. Es muy probable, desde esta perspectiva, que el concepto de Ilustración tenga para nuestro autor este sentido profundo y último de «respeto al orden establecido de las cosas» y de un «buen gusto» al que se opone el «mal gusto» y la «depravación» del despotismo o del "ministerio», «atento siempre a extender las facultades del Soberno» (p. 51).

Sólo desde la atalaya de una pluralidad de espacios patrimonialmente configurados se puede entender el caracter sustantivo de la jurisdicción como lenguaje configurador de derechos en detrimento del lenguaje estrictamente políti$\mathrm{co}^{18}$. El rechazo al «ministerio», sinónimo de capacidad ejecutiva y administrativa, tal como se desprende de la cita anterior, es rotundo en nuestro autor. Su despliegue tiende a confundir aquellos «espacios» y aquellos "particularismos» en cuya defensa cobra razón de ser el horizonte cultural e ideológico del derecho y de la jurisprudencia.

Es por ello que, en el apartado relativo al poder judicial, es donde el discurso de Borrull adquiere sus tonos más brillantes y sugerentes, tratándose como se trata de aquel elemento que, como tendremos ocasión de ver, define de manera más rotunda la especificidad del reino. La justicia, lejos de entenderse como el poder encargado de la administración y aplicación de las leyes, es el auténtico y sustantivo campo de diseño de la estructura social $y$, por tanto, de los derechos $y$ obligaciones de los individuos. Es ella la que determina el campo de juego político y que, en manos del monarca-legislador, se convierte de hecho en un instrumento diseñador y delimitativo de contrapesos y equilibrios. Si hay, efectivamente, algun campo semántico clave en el discurso de Borrull, en tanto que condensador de toda su percepción política y de una peculiar forma de leer y de ver la historia en clave territorial-regional, ese es el que hace referencia a la idea de equilibrio. No se trata ahora ni aquí exclusivamente de un equilibrio ReyReino, sino de una cualidad interna al propio Reino y que lo distingue de la

18 Uno de los pocos estudios existentes sobre Borrull incide precisamente en este calificativo de «lenguaje judicial» para significar la postura política de un «preabsolutismo», distinto tanto de la vía adminsitrativista del absolutismo dieciochesco, como a la política de los liberales, y distinta, por supuesto, a la tradicionalista decimonónica. La «visión judicial» se llega a definir como aquella «según la cual los derechos particularistas y las libertades de la nación deber ser restaurados y respetados, el poder administrativo y la capacidad legislativa deben quedar sujetos al freno y control judicial, y la razón y el consejo (de los intereses del reino) deben prevenir el ejercicio de un poder arbitrario y despótico. Según esta opción, la administración debe realizar la justicia (preservar a cada uno en lo suyo)...» Vid. Aliena Miralles, Rafael: «La teoría política del absolutismo en las primeras Cortes de Cádiz: el lenguaje judicial» en FrADERA, J.M., MILLÁN, J. Y GARRABOU, R. (eds): Carlisme i moviments absolutistes a l'Europa de la primera meitat del segle XIX, Vic, Eumo Edit., 1990, pp. 151-168. 
«desmesura» imperante y observable en otros territorios de la propia corona, como el de Aragón. Este reino y, sobre todo, su nobleza, detentadora del mero y mixto imperio, es el contrapunto en negativo de lo que no puede ser en el momento de pensar una estructura social y política interna. Castilla, seguramente, lo sería en el sentido de la total falta de equilibrio entre los dos polos delimitativos de la constitución estamental, aunque a la postre ambos aspectos esten absolutamente interrelacionados. Frente a ellos y a sus pretensiones, Borrul opondrá la idea de un reparto equilibrado del poder que, a la par que no deje fuera del juego político a ningún sector, permita al mismo tiempo una actuación de fuerzas intermedias que impida a cualquiera de los implicados precipitarse en el exceso. "Conoció también el Soberano - argumenta- no consistir el bien del estado en dar el poder judicial a una sola clase o estamento del mismo con exclusión de la nobleza, sino en que esta no prevaleciese entonces, o lograra ventaja o mayor derecho para su obtento: y que entrando a exercitar el cargo, estuviera (digámoslo así) contenida por una fuerza intermedia que le impidiera precipitarse a qualquier exceso, a que le arrastrara su poder y opulencia» (pp. 39-40) ${ }^{19}$.

La clave interpretativa de esa contención se despliega en Borrull en varias directrices, todas coincidentes. Por una parte, en unos Fueros que, en tanto que auténtico derecho territorial, es decir, «general» por abarcar a todos los elementos políticos y cuerpos de un determinado territorio ${ }^{20}$, establecen unos límites y «contrapesos para mantener igual en dichos pueblos (de señorío) la

19 Las cursivas no están en el original.

20 El Fuero de Valencia, de hecho, aparece para Borrul como elemento superador de las «enfadosas formalidades (...) y de los prolijos trámites y molestadas dilaciones» del derecho canónico y del derecho civil, es decir, del sustrato componente del ius commune. Como nos recuerda B. Clavero, «al mismo tiempo que se va formando el cuerpo textual y el aparato doctrinal del ius commune, entre los siglos XII y XV, en los diversos territorios cristianos van también alcanzando formulación, como resultado de la particular evolución de sus institutos altomedievales, sus respectivos iura propia; esta formulación se lleva a cabo generalmente, aunque no siempre (...) a nivel de reino, integrando bajo un mismo "derecho territorial» al conjunto de potestades o entidades políticas radicadas en él». Clavero, B.: Temas de Historia del Derecho: Derecho común, Sevilla, Publicaciones de la Universidad de Sevilla, 1979, pp. 87-88. Ese "derecho propio», sin embargo, no se resolverá históricamente en Borrull en un arma a favor de la capacidad legislativa y, por tanto, «despótica» del monarca, sino en la salvaguarda de aquellos intereses y derechos intermedios capaces, precisamente, de frenar a ese despotismo. Borrull formaría así parte de la «reacción antiromanista» del siglo XVIII o «nacionalismo antiromanista» que, según el autor citado, "puede funcionar tanto velando las raíces doctrinales del sistema vigente como obstaculizando la recepción de corrientes más renovadoras...» (Ibídem, p. 224). No obstante, la postura de Borrull ante el debate histórico y jurídico en el seno de la Ilustración está todavía por estudiar. Debería tenerse cuidado, en todo cáso, en encajar su postura en un hipotética y más que probable defensa del derecho de propiedad en el nuevo contexto del Estado liberal, no dimanante tanto de un romanismo cosmopolita cuanto de ese «iura propia» que se constituiría así en la permanencia de "particularismos" capaces de sobrevivir en una estructura más general, más centralista y más uniforme. El Tribunal de las Aguas sería una buena muestra de ello, pero seguramente no la única ni la más significativa, aunque sí emblemática. 
balanza de la justicia», reservándose el monarca en todas las causas civiles y criminales «las instancias de recurso y manifiesta opresión» y limitando «el libre exercicio del mero imperio y de un poder absoluto e independiente de las leyes» (p. 42). Por otra parte, en una asimilación del estamento de la nobleza, no a su referente extremo de «señor de horca y cuchillo» o gran nobleza titular de la alta y baja jursidicción, sino a los caballeros o «generosos». Y, por último, en ese «establecimiento» o institución tan valenciana como la «jurisdicción alfonsina», establecida por Alfonso II en 1329, y dentro de la cual, a su vez, cobra significado pleno su idea de nobleza intermedia o media ${ }^{21}$.

La estructura socio-estamental valenciana para Borrull se significa sobre todo por la presencia de dos clases que, sin lugar a dudas han constituido el referente común de una mitología «nacionalista» fuertemente alimentada desde los peculiares aires particularistas de una determinada historiografía romántica: caballeros o «generosos» y plebeyos, prohombres o ciudadanos, políticamente transformados en el estamento de la nobleza y en el estamento real. La perspectiva política del valenciano es tripartita, incluyendo también al estado esclesiástico, pero es muy curioso que éste no reciba prácticamente ninguna mención especial a lo largo de su trabajo.

El estudio comparativo de varias constituciones, con el que Borrull cierra sus páginas, ofrece ya, en realidad pocas sorpresas. Castilla es el modelo de falta de libertad, al quedar reunida en la persona del rey las facultades del legislativo y del ejecutivo. La de Bayona supone para nuestro autor un claro desprecio a leyes fundamentales de la monarquía. Es cierto, y así lo reconoce, que Napoleón restablece las cortes, "pero no las antiguas Cortes de la Nación..., sino unas Cortes sombrías y vanas» en las que la apariencia estamental queda anulada por la disposición de «votos tomados individualmente», «siguiendo el proyecto formado en 1789 por Mr. Necker sobre la confusión de clases para oprimir al clero y a la nobleza en la Junta de los estados generales de Francia» (p. 58).

Mayor indignación le produce el anuncio en esta Constitución, en sus artículos 96 y 113, del establecimiento de un sólo Código civil y criminal para España e Indias. La naturaleza de Ley, dimanante de un espíritu universal y racional, de efectos uniformizadores, resulta totalmente extraña al pensamiento

\footnotetext{
${ }^{21}$ La alfonsina es una peculiaridad del Reino, no desaparecida tampoco tras la abolición de los Fueros en el siglo XVIII y expresamente confirmada por Felipe V en 1708. Se trata de una jurisdicción menor que se concedía a todos aquellos que poblasen o peseyesen un lugar con más de 15 casas, en el término de qualquier ciudad, villa real o de señorío particular, propiciando así, la creación de auténticos «señoríos» menores dependientes, en su caso, de una jurisdicción superior, generalmente de ciudades realengas. Este tipo de nobleza, con un desarrollo mucho más notable de las rentas territoriales sobre las jurisdiccionales sería una de las grandes favorecidas del desarrollo económico del dieciocho valenciano, llegando a la abolición de los señoríos en unas condiciones inmejorables para hacer valer su dominio territorial y transmutarlo en propiedad privada. Sobre todo esto, vid. ROMEU ALFARO, Silvia: «Los Fueros de Valencia y los Fueros de Aragón: Jurisdicción alfonsina» en Anuario de Historia del Derecho español (Madrid) XLII (1972) pp. 75-115.
} 
de Borrull; la ley sólo puede ser expresión y contenedor a un tiempo de particularismos concretos, recogiendo la pluralidad de situaciones y haciéndose eco de la diversidad geográfica, cultural y de costumbres. El anuncio codificador, fruto de otra cultura jurídica y de otra concepción política, es impensable su aplicación en España por «los muchos reynos que comprende, tan distintos entre sí en su clima, situación, qualidad del terreno, necesidades, modo de vivir, inclinaciones, y costumbre de sus habitadores: cuyas circunstancias, según el dictámen de los más juiciosos escritores, obligan a variar las leyes» (p. 61). El Montesquieu de El espíritu de las leyes no anda lejos...

Desde esos presupuestos, no resulta sorprendente el rechazo a «las diferentes Constituciones, que en el corto espacio de diez años, ha visto la Francia nacer, dominar y exterminarse» (p. 63). De la misma manera que tampoco nos debe extrañar el que los mejores elogios se reserven a la «Constitución de Inglaterra», no sólo porque asegura libertad política, sino porque es la expresión más clara de una unión perfecta entre Soberano y Pueblo, al tiempo que un instrumento capaz de un desarrollo económico de primer orden, aunque tampoco ésta quede libre de las suspicacias del tratadista a la hora de una auténtica contención del monarca.

Sólo la Constitución otorgada por el Señor D. Jayme I resisten cualquier tipo de comparaciones; "y sin entrar en odiosas competencias con la que más se celebra hoy en día (la inglesa), dexa muy atrás a algunas de las que regían entonces, y a todas las que han dispuesto en estos últimos tiempo los decantados Filósofos modernos de Francia y el faccioso Napoleón» (p. 68). Sus benéficos efectos, en orden a las letras, las artes, la agricultura, el comercio - a los que Borrull dedica las páginas finales de su escrito-, no harían sino corroborar este juicio. El final de la Historia — dicho sea lo de historia en su sentido más literal y menos irónico- es, lógicamente, la llegada de los Borbones al trono español y el decreto de Nueva Planta que abolió los Fueros de Valencia. Un nuevo tópico queda abierto, entendiendo también aquí lo de tópico en su sentido más exacto de delimitación de un espacio: el que hace referencia a la necesidad de demostrar que el Reino de Valencia no puede se acusado de traición y, por tanto, no se puede alegar derecho de conquista por parte del monarca para deshacer sus Fueros. Anclado en ese necesario planteamiento, el siglo XVIII, toda su trayectoria y toda su evolución, «desaparece» del horizonte intelectual y de la voluntad política de Borrull, de la misma manera que resultará también harto incómodo para otra posterior historiografía, incapaces uno y otras de reconciliar dentro de sus esquemas el siglo que supuso, contradictoriamente, el asomo mayor de «despotismo» junto con un crecimiento que aseguró, al menos para el País Valenciano, el desarrollo y consolidación de esos «señores» o «nobles intermedios». Precisamente de esos sectores sociales por los que tan ardientemente batalló Borrull. Una curiosa y paradójica cuadratura del círculo... 